\title{
Peningkatan Ketebalan Serat Elastin Dinding Vagina pada Prolapsus Organ Pelvis Anterior
}

\author{
Increased Thickness of Elastin Fibre on Vaginal Wall of Aiunterior Pelvic Organ Prolapse
}

Achmad Zaki', Eighty Mardian K', Sjahjenny Mustokoweni

'Departemen Obstetri dan Ginekologi, ${ }^{2}$ Departemen Patologi Anatomi

Fakultas Kedokteran, Universitas Airlangga, RSUD Dr Soetomo, Surabaya

\begin{abstract}
ABSTRAK
Tujuan: Mengukur ketebalan serat elastin pada dinding vagina penderita POP anterior dan menganalisis korelasi antara ketebalan serat elastin dengan derajat POP anterior.

Bahan dan Metode: Penelitian ini merupakan penelitian analitik observasional secara cross sectional yang dilakukan pada 28 blok paraffin dinding vagina dari penderita POP anterior yang telah dilakukan operasi di RSUD dr. Soetomo Surabaya. Dibagi menjadi 4 kelompok: derajat 0/I, II, III dan IV dengan masingmasing $(n=7)$. Dilakukan pewarnaan imunohistokimia dengan antibodi elastin dilanjutkan pengukuran ketebalan serat elastin menggunakan mikroskop dengan perangkat lunak Leica Application Suite (LAS).

Hasil: Didapatkan perbedaan bermakna rerata ketebalan serat elastin kelompok penderita POP anterior derajat 0/I, II, III dan IV yaitu masing-masing sebesar $0,81 \pm 0,14 \mu \mathrm{m} ; 1,63 \pm 0,19 \mu \mathrm{m}$; $2,47 \pm 0,26 \mu \mathrm{m}$ dan $3,19 \pm 0,36 \mu \mathrm{m}(\mathrm{p}<0,0001)$. Berdasarkan hasil uji statistik korelasi pearson didapatkan koefisien korelasi $\mathrm{r}=$ $0,965(\mathrm{P}<0,0001)$.

Simpulan: Ketebalan serat elastin pada dinding vagina bertambah dengan meningkatnya derajat POP anterior. Peningkatan ketebalan serat elastin merupakan akibat proses remodeling matriks ekstraseluler pada dinding vagina penderita POP anterior.
\end{abstract}

Kata kunci: Prolapsus organ pelvis, Elastin, Dinding vagina

\begin{abstract}
Objectives: To measure the thickness of elastin fibres on vaginal wall of patients with POP anterior and then analyse the correlation of this measurement with the degree of POP anterior.

Materials and Methods: This research is an observational analytic study. Data collection was conducted with a cross sectional approach on 28 blocks paraffin of vaginal wall taken from POP anterior patients of whom went through an operation in Dr. Soetomo Hospital of Surabaya. Data was divided into four groups: degree 0/I, II, III and IV respectively $(\mathrm{n}=7)$. Immunohistochemical staining was performed with antibodies elastin. Afterward, the thickness of the elastin fibres was measured by utilizing a microscope with a Leica Application Suite (LAS) software.

Results: We found significant differences in the mean of thickness of elastin fibres in each group of patients with degrees of anterior POP $0 / \mathrm{I}, \mathrm{II}, \mathrm{III}$ and IV respectively $0,81 \pm 0,14 \mu \mathrm{m}$; $1,63+0,19 \mu \mathrm{m} ; 2,47+0,26 \mu \mathrm{m}$ and $3,19+0,36 \mu \mathrm{m}(\mathrm{p}<0,0001)$. Based on Pearson correlation test, the results shows a correlation coefficient $r=0.965$ ( $p<0,0001)$.

Conclusion: The thickness of elastin fibre on vaginal wall increased as the degree of POP anterior arise. Increased in the thickness of elastin fibers on the vaginal walls was the result from extracellular matriks remodelling on vaginal wall of anterior POP patient.
\end{abstract}

Keywords: Pelvic organ prolapse, elastin, vaginal wall

Correspondence: Achmad Zaki, Departemen Obstetri dan Ginekologi, Fakultas Kedokteran, Universitas Airlangga, RSUD Dr Soetomo, Jalan Prof dr Moestopo 6-8, Surabaya 60286, Indonesia.

\section{PENDAHULUAN}

Prolapsus organ pelvis (POP) adalah turunnya satu atau lebih organ pelvis (kandung kemih, uterus, vagina) dari posisi anatomi normalnya ke arah introitus vagina. POP merupakan kelainan yang sering mengakibatkan permasalahan serius pada kualitas hidup seorang wanita. Namun pengobatan POP sampai saat ini masih belum optimal. Hal ini karena terdapat bermacam hipotesis mekanisme yang berperan dalam terjadinya POP namun tidak ada satupun yang dapat menjelaskan secara tegas penyebab POP. Dari penelitian epidemiologis didapatkan dua faktor resiko mayor terjadinya POP yaitu persalinan pervaginam dan usia penderita. Faktor resiko lain seperti peningkatan tekanan abdomen, obesitas dan menopause. Namun tidak semua wanita dengan faktor resiko tersebut mengalami POP. ${ }^{1,2,3}$

POP anterior merupakan jenis yang paling sering ditemukan. Dimana terjadi penurunan dari kandung kemih yang dikenal dengan istilah sistokel. Jaringan ikat pada dinding anterior vagina merupakan penyokong utama untuk dasar kandung kemih. Kelemahan jaringan ikat pada dinding vagina atau perlekatan dinding vagina pada otot dasar panggul dapat merupakan patogenesis dari POP. Ini dibuktikan pada penderita dengan kelainan jaringan ikat kongenital seperti sindrom Ehlers-Danlos, sindrom Marfan dan sindrom Cutis laxa didapatkan resiko kelainan dasar panggul seperti POP dan inkontinensia urine lebih besar. ${ }^{1,4,5}$ 
Jaringan ikat pada vagina terdiri atas fibroblas dan sel otot polos yang dikelilingi oleh matriks ekastraseluler. Kolagen dan elastin merupakan komponen utama matriks ekstraselular yang menentukan kekuatan jaringan. ${ }^{1,3}$ Elastin memiliki peran yang sangat penting dalam pemanjangan, kelenturan dan pemendekan kembali jaringan ikat penyokong organ pelvis. Pada beberapa penelitian didapatkan terjadi penurunan kadar elastin pada penderita POP. $^{2}$ Sampai saat ini belum pernah dilakukan penelitian hubungan ketebalan serat elastin pada dinding vagina dengan derajat prolapsus organ pelvis anterior. Selanjutnya melalui penelitian ini diharapkan dapat memahami peran elastin dalam patofisiologi POP anterior.

\section{BAHAN DAN METODE}

Penelitian ini adalah penelitian analitik observasional secara cross sectional. Penelitian dilakukan di bagian Rekam Medis dan Laboratorium Patologi Anatomi RSUD dr. Soetomo Surabaya pada bulan Agustus 2015 s/d Oktober 2015. Populasi penelitian adalah penderita kelainan ginekologi yang telah dilakukan operasi di RSUD Dr. Soetomo Surabaya.

Sampel penelitian adalah penderita POP anterior derajat II,II dan IV yang telah dilakukan operasi Transvaginal Histerektomi (TVH) dan penderita POP anterior derajat 0/I yang telah dilakukan operasi Transabdominal Histerektomi (TAH) atas indikasi tumor ginekologi jinak serta didapatkan blok paraffin potongan dinding vagina anterior pada pemeriksaan Patologi Anatomi. Pengambilan sampel dilakukan secara konsekutif.

Kriteria Eksklusi pada penelitian ini yaitu penderita dengan kelainan genetik jaringan ikat seperti Sindrom Marfan, Sindrom Ehler Danlos dan Sindrom Cutis Laxa. Penderita dengan penyakit keganasan organ pelvis dan blok paraffin rusak atau tidak bisa dibaca.

Pada sampel penelitian yang telah memenuhi kriteria inklusi dan eksklusi dilakukan pengambilan data demografi pasien di bagian Rekam medis RSUD dr. Soetomo. Kemudian dilakukan pengambilan sampel dari Blok parafin potongan vagina di Bagian Laboratorium Patologi Anatomi RSUD dr. Soetomo. Dilakukan pemeriksaan imunohistokimia dengan antibodi elastin untuk menilai serat elastin. Dilanjutkan dengan pengukuran ketebalan serat elastin. Dari hasil pemeriksaan ketebalan serat elastin dilakukan analisis statistik.

Pemeriksaan immunohistokimia dengan memakai teknik indirect immunoenzyme. Blok paraffin dipotong dan dilakukan deparafinisasi dengan direndam xylol. Cuci slide dengan phosphate buffer saline (PBS).
Diberikan antibodi primer mouse monoclonal anti human elastin menggunakan kit antibodi elastin (NB 100-2076, Novus Biological, USA) dengan pengenceran 1:50 kemudian diinkubasi pada Magnetic immunostaining dalam keadaan tertutup dengan suhu 4 derajat celcius selama semalam (Overnight).

Diberikan antibodi sekunder anti mouse biotini. Diberikan antibodi sekunder Streptavidin peroksidase label. Diberikan peroksidase dan diaminobenzidine (DAB). Dilakukan counterstain dengan mayer hematoxylin. Pewarnaan antibodapat dilihat dibawah mikroskop dan dilanjutkan pengukuran ketebalan serat elastin setiap sampel menggunakan mikroskop dengan perangkat lunak Leica Application Suite (LAS) dalam satuan mikrometer $(\mu \mathrm{m})$

\section{HASIL DAN PEMBAHASAN}

Dari data register pasien di Bagian Uroginekologi RSUD dr. Soetomo Surabaya periode Januari 2013 September 2015 kami dapatkan jumlah total penderita POP anterior yang telah dilakukan operasi TVH sebanyak 42 penderita. Kemudian kami cari data di rekam medis selanjutnya diseleksi berdasarkan kriteria inklusi dan ekslusi didapatkan 33 data penderita. Kemudian kami cari blok paraffin dinding vagina anterior di laboratorium PA yang memenuhi syarat pemeriksaan ada 21 slide dengan rincian POP anterior derajat II, III dan IV masing-masing 7 slide.

Pada penelitian ini untuk penderita POP anterior derajat 0/I yaitu pasien yang telah dilakukan operasi TAH atas indikasi tumor jinak kandungan seperti mioma uteri, kista ovarium dan hiperplasia endometrium. Kami dapatkan 10 penderita POP anterior derajat 0/I yang telah dilakukan operasi. Kemudian kami cari blok paraffin dinding vagina anterior di laboratorium PA yang memenuhi syarat pemeriksaan ada 7 slide.

Selama periode penelitian keseluruhan sampel yang kami dapatkan berjumlah 28 sampel penderita POP anterior. Dimana sampel ini dibagi menjadi 4 kelompok derajat POP anterior yaitu kelompok derajat 0/I, derajat II, derajat III dan derajat IV dengan masing-masing jumlah sampel 7 perkelompok.

Tabel 1. Karakteristik Sampel Penelitian

\begin{tabular}{lccccc}
\hline \multirow{2}{*}{ Karakteristik } & \multicolumn{3}{c}{ Kelompok derajat POP anterior } & \multirow{2}{*}{$\mathrm{p}$} \\
\cline { 2 - 5 } & $\mathrm{O} / \mathrm{I}(\mathrm{n}=7)$ & $\mathrm{II}(\mathrm{n}=7)$ & III $(\mathrm{n}=7)$ & IV $(\mathrm{n}=7)$ & \\
\hline Usia (tahun) & $52.1 \pm 3.9$ & $58.8 \pm 10.7$ & $59.0 \pm 8.0$ & $58.1 \pm 5.1$ & 0.276 \\
Paritas & $3.5 \pm 2.3$ & $3.2 \pm 1.7$ & $3.2 \pm 0.4$ & $3.2 \pm 1.3$ & 0.984 \\
Menopause (\%) & 71.4 & 71.4 & 85.7 & 85.7 & 0.418 \\
\hline
\end{tabular}



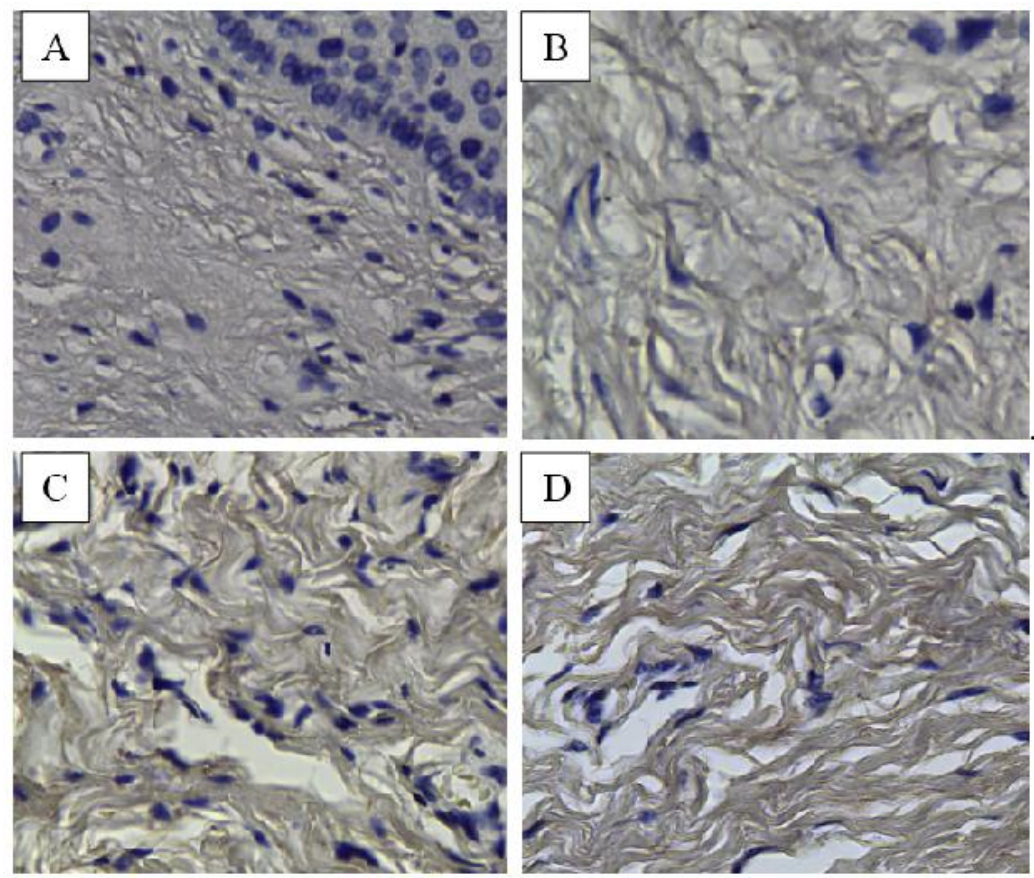

Gambar 1. Hasil pewarnaan imunohistokimia elastin pada dinding vagina penderita POP anterior (Pembesaran 400x): A. Derajat 0/I, B. Derajat II, C. Derajat III dan D. Derajat IV

Pada keempat kelompok derajat POP anterior didapatkan usia penderita, jumlah paritas dan status menopause yang bervariasi. Kami lakukan uji homogenitas sampel terhadap usia penderita, jumlah paritas dan status menopause. Dari keempat kelompok, tidak didapatkan perbedaan yang bermakna. Sehingga dapat disimpulkan bahwa sampel yang digunakan homogen

\section{Ketebalan Serat Elastin}

Pengukuran ketebalan serat elastin pada masing-masing slide dilakukan pada 5 lapangan pandang secara acak dengan pembesaran 400x. Pada setiap lapangan pandang diukur 5 serat elastin dalam satuan mikrometer $(\mu \mathrm{m})$ dengan perangkat lunak LAS kemudian didapatkan nilai rerata tebal serat elastin.

Tabel 2. Ketebalan serat elastin antar kelompok

\begin{tabular}{lccc}
\hline Derajat & $\begin{array}{c}\text { Jumlah } \\
\text { Rerata } \pm \text { SD (um) }\end{array}$ & $\mathrm{p}$ \\
& (n) & & \\
\hline 0/I & 7 & $0,81 \pm 0,14^{\mathrm{a}}$ & \\
II & 7 & $1,63 \pm 0,19^{\mathrm{b}}$ & $\mathrm{p}<0,0001$ \\
III & 7 & $2,47 \pm 0,26^{\mathrm{c}}$ & \\
IV & 7 & $3,19 \pm 0,36^{\mathrm{d}}$ & \\
\hline \multicolumn{4}{l}{ Keterangan: } \\
\multicolumn{4}{c}{ Superscript yang berbeda menunjukkan perbedaan } \\
bermakna
\end{tabular}

Berdasarkan hasil uji statistik seperti terlihat pada tabel 2 , didapatkan rerata ketebalan serat elastin kelompok penderita POP anterior derajat 0/I, II, III dan IV yaitu masing-masing sebesar $0,81 \pm 0,14 \mu \mathrm{m} ; 1,63 \pm 0,19 \mu \mathrm{m}$; $2,47 \pm 0,26 \mu \mathrm{m}$ dan $3,19 \pm 0,36 \mu \mathrm{m}$. Perhitungan statistik pada penelitian ini menggunakan tingkat kemaknaan 0,05 (confident interval 95\%). Didapatkan hasil $\mathrm{p}<0,0001$ menunjukkan perbedaan yang bermakna.

Dengan melihat hasil dari analisis post hoc, secara statistik terdapat perbedaan ketebalan serat elastin antar kelompok derajat POP anterior karena nilai $\mathrm{p}<0,0001$ dengan IK 95\%. Dengan demikian didapatkan perbedaan bermakna ketebalan serat elastin antar masingmasing kelompok derajat 0/I, II, III dan IV. Berdasarkan hasil uji korelasi dari pearson didapatkan koefisien korelasi $\mathrm{r}=0,965(\mathrm{P}<0,0001)$. Berarti terdapat hubungan korelasi positif kuat antara ketebalan serat elastin dengan derajat POP anterior.

\section{Karakteristik Pasien}

\section{Usia Penderita}

Kami dapatkan rata-rata usia penderita POP anterior pada kelompok derajat $0 / \mathrm{I}$, derajat II, derajat III dan derajat IV masing-masing sebesar $52,1 \pm 3,9$ tahun; 58,8 $\pm 10,7$ tahun; $59,0 \pm 8,0$ tahun dan $58,1 \pm 5,1$ tahun. 
Dari uji statistik pada keempat kelompok, tidak didapatkan perbedaan usia penderita yang bermakna ( $\mathrm{P}$ $<0,0001)$.

Hasil ini sesuai dengan beberapa penelitian sebelumnya, dimana POP terjadi hampir pada separuh wanita usia berusia di atas 50 tahun dengan prevalensi mencapai 30$50 \%$. Pada penelitian nizomy dkk kasus POP di RSUD dr. Soetomo tahun 2007-2011 didapatkan rata-rata usia penderita $58,5+10,5$ tahun. Dari hasil analisis regresi logistik didapatkan faktor usia memiliki hubungan yang bermakna dengan kejadian POP $(\mathrm{P}=0,046)$. Pada penelitian di RS Dr. Mohammad Hoesin Palembang didapatkan kasus POP terbanyak pada penderita usia antara 45-64 tahun yaitu 65,12\%. Pada penelitian di RS M. Jamil Padang didapatkan yang terbanyak pada penderita usia $>50$ tahun yaitu $21,56 \%$. ${ }^{9}$

\section{Jumlah Paritas}

Kami dapatkan rata-rata jumlah paritas penderita POP anterior pada kelompok derajat 0/I, derajat II, derajat III dan derajat IV masing-masing sebesar 3,5 $\pm 2,3 ; 3,2 \pm$ 1,$7 ; 3,2 \pm 0,4$ dan $3,2 \pm 1,3$. Dari uji statistik tidak didapatkan perbedaan jumlah paritas yang bermakna $(\mathrm{P}<0,0001)$. Hasil ini sesuai dengan yang didapatkan pada banyak penelitian bahwa multiparitas merupakan faktor resiko utama yang berhubungan dengan prevalensi POP.

Pada penelitian Nizomy dkk didapatkan rata-rata jumlah paritas penderita POP di RSUD dr. Soetomo Surabaya tahun 2007-2011 yaitu 4,89 $\pm 2,69$. Pada penelitian di RSCM didapatkan paritas lebih dari 3 memiliki resiko tinggi terjadinya POP. Sedangkan pada penelitian di RS M. Jamil Pada dan RS Dr. Mohammad Hoesin Palembang yang terbanyak yaitu grande multipara sebesar $40,03 \%$ dan $47,44 \%{ }^{9}$

\section{Status Menopause}

Kami dapatkan persentase status menopause penderita POP anterior pada kelompok derajat 0/I, derajat II, derajat III dan derajat IV masing-masing sebesar 71,4\%; $71,4 \%$; 85,7\%; dan 85,7\%. Dari uji statistik keempat kelompok, tidak didapatkan perbedaan status menopause yang bermakna $(\mathrm{P}<0,0001)$.

Hasil ini juga sesuai dengan penelitian sebelumnya dimana POP banyak ditemukan pada penderita yang sudah menopause. Pada penelitian Nizomy dkk penderita POP di RS Dr. Sutomo Surabaya tahun 20072011 didapatkan 76 kasus $(85,87 \%)$ sudah menopause. Pada penelitian di RS Mohammad Hoesin Palembang yaitu $76,05 \%$ penderita sudah menopause. ${ }^{9}$

\section{Ketebalan Serat Elastin}

Pada hasil pengukuran ketebalan serat elastin didapatkan perbedaan rerata ketebalan serat elastin kelompok penderita POP anterior derajat 0/I , II, III dan IV yaitu masing-masing sebesar $0,81 \pm 0,14 \mu \mathrm{m} ; 1,63 \pm 0,19$ $\mu \mathrm{m} ; 2,47 \pm 0,26 \mu \mathrm{m}$ dan $3,19 \pm 0,36 \mu \mathrm{m}(\mathrm{p}<0,0001)$. Pada uji statistik post hoc untuk menilai perbedaan masing-masing kelompok, didapatkan perbedaan bermakna ketebalan serat elastin antar masing-masing kelompok derajat 0/I, II, III dan IV ( $<<0,0001)$. Hasil ini menunjukkan ketebalan serat elastin semakin bertambah secara bermakna dengan meningkatnya derajat POP anterior.

Berdasarkan hasil uji statistik korelasi pearson didapatkan koefisien korelasi $\mathrm{r}=0,965 \quad(\mathrm{P}<0,0001)$. Berarti terdapat hubungan korelasi positif kuat antara ketebalan serat elastin dengan derajat POP anterior. Hasil ini tidak sesuai dengan hipotesis penelitian kami bahwa ketebalan serat elastin semakin rendah dengan meningkatnya derajat POP anterior.

Hasil pada penelitian ini sesuai dengan penelitian Kerkhof dkk yang membandingkan ekspresi elastin pada dinding vagina anterior 13 wanita dengan POP anterior yang dilakukan TVH dengan 13 wanita tanpa POP anterior yang dilakukan histerektomi karena tumor ginekologi jinak. Didapatkan bahwa tidak ada perbedaan bermakna ekspresi elastin secara statistik, namun didapatkan kecenderungan peningkatan ekspresi elastin pada penderita POP anterior dibanding tanpa POP $(3,04 \%$ vs $2,17 \%)$. Didapatkan juga peningkatan ekspresi elastin dengan bertambahnya derajat POP, dimana didapatkan ekspresi elastin lebih tinggi pada POP berat dibanding POP ringan $(3,85 \%$ vs $2,27 \%){ }^{8}$ Pada penelitian Zong dkk didapatkan jumlah tropoelastin meningkat $(432 \%, \mathrm{P}<0,001)$ dan jumlah elastin matur meningkat melalui peningkatan ekspresi desmosine $(55 \%, \quad \mathrm{P}=0,019)$ pada wanita dengan $\mathrm{POP}$ dibanding kontrol. ${ }^{10}$

Penelitian tentang elastin pada jaringan manusia masih merupakan tantangan. Elastin dapat diperiksa pada tingkatan mRNA elastin, tingkatan prekusor protein elastin atau pada tingkat serat elastin matur. Pemeriksaan pada tingkat ekspresi mRNA elastin tidak dapat menunjukkan kondisi sebenarnya elastin pada jaringan karena masih melalui proses translasi dan modifikasi dimana proses ini tidak dapat dinilai melalui pemeriksaan mRNA elastin. Pemeriksaan elastin melalui ekspresi tropoelastin namun ini hanyalah prekusor protein dari elastin sehingga kondisi sebenarnya dari serat elastin matur tidak dapat dinilai. Pemeriksaan kuantitas elastin matur melalui pemeriksaan indirek pada ikatan desmosine namun pemeriksaan inipun tidak akurat 
karena perubahan pada jaringan sehubungan dengan POP akan mempengaruhi ikatan ini. Pemeriksaan lain melalui tehnik western blot namun keterbatasannya semua elastin akan terukur termasuk elastin pada dinding pembuluh darah di jaringan sehingga pemeriksaan menjadi tidak akurat. ${ }^{11}$

Pada penelitian ini kami melakukan pemeriksaan ketebalan serat elastin dengan identifikasi serat elastin matur melalui pemeriksaan imunohistokimia dengan menggunakan kit antibodi elastin (NB 100-2076, Novus Biological, USA) dilanjutkan dengan pengukuran ketebalan serat elastin. Dari hasil pemeriksaan kami dapatkan kuantitas serat elastin matur berupa ketebalan serat yang semakin bertambah dengan meningkatnya derajat POP anterior. Kami melakukan pengukuran ketebalan serat elastin bukan ekspresi elastin seperti pada beberapa penelitian sebelumnya. Hal ini karena yang dinilai adalah serat elastin matur yang merupakan komponen matriks ekstraseluler. Sehingga untuk mengukur kuantitas dari serat elastin yang lebih objektif adalah dengan mengukur ketebalan dari serat elastin matur. Hal ini mungkin yang dapat menyebabkan hasil penelitian kami berbeda dengan penelitian sebelumnya.

Pada penelitian ini kami hanya menilai kuantitas dari serat elastin melalui pengukuran ketebalan serat elastin matur sedangkan kualitas dari serat elastin itu sendiri membutuhkan pemeriksaan lain untuk menilai enzim atau protein lain yang berperan dalam sintesis dan degradasi elastin misalnya LOXL1, fibulin 5, NE, MMP-2 dan MMP-9. Sehingga walaupun kuantitas serat elastin meningkat namun dapat saja kualitasnya buruk sehingga mengakibatkan jaringan dinding vagina menjadi lemah. Ini berarti serat elastin yang semakin menebal dapat menunjukkan serat elastin yang defek. Ini sesuai dengan gambaran serat elastin yang ditunjukkan pada kelainan jaringan ikat elastin pada kulit dapat berupa serat elastin yang membengkak, terpecah-pecah dan irregular. Sebaliknya pada jaringan kulit normal gambaran serat elastin normal berupa serat tipis. ${ }^{12}$

Beberapa penelitian sebelumnya telah melaporkan tentang perubahan serat elastin pada POP. Penelitian Karam dkk melaporkan bahwa ekspresi elastin dan tebal serat elastin lebih rendah pada dinding vagina penderita dengan sistokel berat dibandingkan kontrol. Namun terdapat beberapa kelemahan pada penelitian ini dimana kontrol yang digunakan adalah penderita kanker urothelial kandung kemih yang dilakukan radikal sistektomi. Padahal secara teoritis diketahui bahwa kanker dapat mempengaruhi kondisi matriks ekstraseluler. Pemeriksaan serat elastin pada penelitian inipun hanya terbatas pada lapisan muskularis dinding vagina. ${ }^{11}$
Penelitian lain oleh Supriadi dkk melaporkan terdapat penurunan kandungan elastin dan tebal serat elastin pada ligamentum sakrouterina pada perempuan dengan prolapsus uteri. Pada penelitian ini jaringan yang diperiksa berbeda karena tidak dilakukan pada dinding vagina. ${ }^{13}$

Terjadinya cedera pada otot levator ani dan jaringan ikat akibat persalinan, menyebabkan peningkatan tekanan intraabdominal secara langsung pada dinding vagina. Hal ini meningkatkan beban mekanik pada dinding vagina sehingga meningkatkan regangan pada jaringan. Beban mekanik telah diketahui dapat mengubah remodeling jaringan dengan meningkatkan MMP oleh fibroblast pada dinding vagina yang dapat mendegradasi serat elastin. $^{8}$

Pada kebanyakan kasus, jaringan vagina dapat membaik dari kejadian akut tersebut dengan remodeling jaringan yang tepat. Namun apabila mekanisme perbaikan ini gagal maka penderita masuk dalam fase kronis. Pada fase kronis terjadi peningkatan tekanan intra abdomen sehubungan dengan bertambahnya derajat POP, obesitas, batuk lama dan kegiatan berhubungan dengan angkat berat. Peningkatan tekanan intra abdomen ini akan secara langsung menekan dinding vagina. Peningkatan beban mekanik ini menyebabkan peregangan pada jaringan ikat sehingga mengakibatkan perubahan pada sintesis matriks ekstraseluler termasuk elastin. ${ }^{8,10}$

Pada fase ini dinding vagina mencoba mengatasi akibat peningkatan tekanan biomekanis dari prolapsus jaringan dan organ. Kemampuan ini dapat dihasilkan melalui respon fibroblas terhadap peningkatan regangan mekanis secara terus menerus. Pada penelitian Kerkhof dkk didapatkan jumlah elastin semakin meningkat pada POP berat serta peningkatan enzim elastolitik protease MMP-9. Hal ini tidak mengejutkan, ini lebih merupakan gambaran efek sekunder dari bertambahnya derajat prolapsus. Dinding vagina mengalami remodeling untuk mengakomodasi perubahan beban mekanik yang semakin bertambah dan berlangsung kronis. Terjadinya kegagalan keseimbangan antara sintesis dan degradasi elastin merupakan indikator jaringan yang tidak stabil pada remodeling penderita POP. ${ }^{8,10}$

Elastin berperan besar dalam mempertahankan integritas dari jaringan ikat namun faktor yang mempengaruhi serat elastin secara umum belum diketahui secara jelas. Sintesis jaringan elastin dewasa sebagai respon terhadap regangan siklis, cedera, radiasi UV dan beberapa penyakit. Namun pada dewasa tidak dapat membentuk kembali mekanisme pemasangan serat elastin normal dan konsekuensinya fungsi menjadi tidak normal. ${ }^{14}$ 
Berdasarkan penelitian ini dimana ketebalan serat elastin semakin bertambah pada dinding vagina dengan meningkatnya derajat POP anterior. Hal ini menunjukkan bahwa perubahan pada jaringan ikat pada POP anterior merupakan efek dapatan pada jaringan ikat. Ini artinya perubahan pada jaringan ikat dinding vagina lebih merupakan gambaran efek sekunder dari prolapsus pada jaringan daripada merupakan penyebab dari prolapsus. $^{8}$

\section{SIMPULAN}

Ketebalan serat elastin pada dinding vagina bertambah dengan meningkatnya derajat POP anterior. Perubahan ketebalan serat elastin pada dinding vagina merupakan efek sekunder akibat proses remodeling matriks ekstraeluler pada penderita POP anterior.

\section{DAFTAR PUSTAKA}

1. Word RA, Pathi S and Schaffer JI. Pathophysiology of Pelvic Organ Prolapse. Obstet Gynecol Clin N Am. 2009;36:521-39.

2. Moon YJ, Choi JR, Kim SK and Bai SW. Alteration of Elastin Metabolism in Women With Pelvic Organ Prolapse. J Urol. 2011;185:1786-92.

3. Landsheere LD, Munaut C, Nusgens B, Maillard C, Rubod C, Nisolle M, Cosson M and Foidart JM. Histology of the vaginal wall in women with pelvic organ prolapse: a literature review. Int Urogynecol J. 2013;192.

4. Lin SY, Tee YT, Ng SC, Chang H, Lin PP and Chen GD. Changes in the extracellular matrix in the anterior vagina of women with or without prolapsed. Int Urogynecol J. 2007;18:43-8.

5. Epstein LB, Graham CA and Heit MH. Systemic and vaginal biomechanical properties of women with normal vaginal support and pelvic organ prolapse. Am J Obstet Gynecol. 2007;197:165-70.

6. Wu MP. Regulation of Extracellular Matrix Remodeling Associated With Pelvic Organ Prolapse. J Exp Clin Med. 2010;2(1):11-6.

7. Klutke J, Ji Q, Campeau J, Starcher B, Felix JC, Stanczyk FZ and Klutke C. Decreased endopelvic fascia elastin content in uterine prolapsed. Acta Obstet Gynecol Scand. 2008;87:111-5.

8. Kerkhof MH, Zapata ALM, Bril H, Bleeker MCG, Belien JAM, Stoop R and Helder MN. Changes in tissue composition of the vaginal wall of premenopausal women with prolapsed. Am J Obstet Gynecol. 2013;210:168.

9. Nizomy IR, Prabowo RP and Hardianto G. Hubungan antara faktor risiko dan kejadian POP di Poliklinik kandungan RSUD dr Soetomo Surabaya tahun 2007-2011. Penelitian Fakultas Kedokteran Universitas Airlangga Surabaya. 2012.

10. Zong W, Stein SW, Starcer B, Meyn LA and Moalli PA. Alteration of vaginal elastin metabolism in women with pelvic organ prolapsed. Obstet Gynecol. 2010;115(5):953-61.

11. Karam JA, Vazquez DV, Lin VK and Zimmern PE. Elastin expression and elastic fibre width in the anterior vaginal wall of postmenopausal women with and without prolapsed, BJU Internasional. 2007; 100:346-50.

12. Uitto J. Biochemistry of the Elastic fiber in Normal Connective Tissues and its Alterations in Diseases, J Invest Dermatol. 1979;72:1-10.

13. Supriadi E, Gandamihardja S and Armawan E. Kandungan Elastin dan Tebal Serat Elastis Ligamentum Sakrouterina pada Perempuan dengan Prolaps Uteri. Indones J Obstet Gynecol. 2011;35:79-83.

14. Goepel C. Differential elastin and tenascin immmunolabeling in the uterosacral ligaments in postmenopausal women with and without pelvic organ prolapsed. Acta histochemica. 2008;110:2049. 